\title{
Historical data on European bison management in Białowieża Primeval Forest can contribute to a better contemporary conservation of the species
}

\author{
Tomasz Samojlik $^{1}$ (ID) Anastasia Fedotova ${ }^{2,3} \cdot$ Tomasz Borowik $^{1} \cdot$ Rafał Kowalczyk $^{1}$ \\ Received: 2 January 2019 /Revised: 10 May 2019 / Accepted: 17 May 2019 / Published online: 13 June 2019 \\ (C) The Author(s) 2019
}

\begin{abstract}
Many mammal species have been extensively impacted by human interventions in the past. It was especially important for endangered or key species such as European bison Bison bonasus, which has a long history of human interventions and is currently a refugee species confined by anthropogenic activities to suboptimal forest habitats. Using archival information (17951915) on bison population dynamics and management practices in Eastern Poland's Białowieża Primeval Forest (BPF) in three periods (1795-1860, 1861-1888, 1889-1915) differing in management goals, we identify the main factors affecting bison numbers and discuss implications of this knowledge for modern conservation of the species. Mean annual increase rate of bison population varied between $3.03 \%$ in the first, $-3.04 \%$ in the second, and $2.69 \%$ in the third period. The most important drivers of European bison population dynamics were the increasing supplementary feeding and anthropogenic offtake (annual number of individuals hunted, live-captured and poached), along with opening of the forest by different traditional activities. Although this management was solely directed at hunting goals, relatively low intensity of animal removal and counteracting effect of supplementary feeding secured the survival of the species. However, management practices applied in all three periods acted against natural selection and increased animal dependence on human support. Collected historical data presents a unique longterm assessment of management practices and their effectiveness and allows to draw conclusions for the current management of the species. Historical management was not based on evidence. The general principles of traditional bison management were adapted by the twentieth-century management of reinstated population. To avoid repeating the same mistakes, the contemporary management model needs revaluation and changes to conform to up-to-date knowledge on the species habitat selection and forage requirements. Continuation of traditional management practices will sustain species refugee status.
\end{abstract}

Keywords Historical ecology · Environmental history $\cdot$ Bison bonasus · Conservation management · Supplementary feeding · Historical data $\cdot$ Refugee species

Communicated by: Jan M. Wójcik

Electronic supplementary material The online version of this article (https://doi.org/10.1007/s13364-019-00437-2) contains supplementary material, which is available to authorized users.

Tomasz Samojlik samojlik@ibs.bialowieza.pl

1 Mammal Research Institute, Polish Academy of Sciences, ul. Stoczek 1c, 17-230 Białowieża, Poland

2 St Petersburg branch, Institute for the History of Science and Technology, Russian Academy of Sciences, Universitetskaia nab. 5, St. Petersburg 199034, Russia

3 Department III, Max Planck Institute for the History of Science, Boltzmannstraße 22, 14195 Berlin, Germany

\section{Introduction}

In recent decades, historical information has been widely used in ecological studies facilitating many conservation actions (Szabó and Hédl 2011; Szabó 2015). Setting conservation goals requires knowledge on ecological baselines and reference conditions, which modern datasets most often do not offer. This had led to transcending disciplinary boundaries in search of historic ecological data, which were then successfully incorporated in conservation studies. Historical data on population dynamics and management strategies were crucial in setting current conservation and management plans across diverse animals, e.g. marine animals (McClenachan et al. 2012; Lajus et al. 2013; Lotze and Worm 2009), amphibians (Muths et al. 2016), and terrestrial mammals (Clavero and 
Delibes 2013). In turn, lack of historical information (either connected with their low availability or neglect) on how animals responded to changes in environmental conditions can lead to setting inadequate goals and cause problems with implementation of conservation measures (Bilney 2014; McClenachan et al. 2016). Historical data on ungulate populations usually encompass information on exploitation process which may have led to population decline or local eradication and, in some cases, species extinction (Freese et al. 2007; Bonebrake et al. 2010). The demand for the comprehensive use of historical data sources in species conservation strategies has become increasingly important (Turvey et al. 2015), especially in the light of rising "shifting baseline syndrome" (Papworth et al. 2009), meaning the lowering of standards of what is considered "natural" by each consecutive generation due to lack of historical knowledge. This has been addressed in many conservation guidelines, e.g. conservation strategy of animals should take into account detailed study of a species' historical distribution (IUCN/SSC 2008). Knowledge about past animal ranges and abundance is essential in establishing reintroduction and translocation programs (IUCN/SSC 2013).

One of the major problems with using historical data in ecological analyses or conservation planning is their fragmentation, and descriptive character (Dean and Milton 2003; Haggan et al. 2007), but more frequently problems with finding a common language between ecologists and historians. However, in recent years, an interdisciplinary approach has successfully solved this limitation (e.g. Jamrichová et al. 2017; Lajus et al. 2007; Armstrong et al. 2017). Still, ecological studies have been rarely based on datasets spanning over a period exceeding 100 years. Most often, archival material contains only presence-absence data, which is still valuable source of information for conservation biologists and managers (Whittlesey et al. 2018) or data on commercially exploited animals (e.g. whales, see Hacquebord 2001).

The need for historical data on population dynamics and ecology is especially important for developing current conservation and management plans for endangered or key species such as European bison Bison bonasus (Kerley et al. 2012). To elaborate an adequate conservation plan, access to data beyond simple records of occurrence is crucial. However, historical insights into management practices are rare, especially for periods before the beginning of the twentieth century. The novel contribution of this paper is the historical data presenting a unique long-term assessment of management practices and their effectiveness. Analysis of this data allows to draw conclusions for the current management of the species. Since restoration of the species, after its extirpation in the wild, the conservation plan of European bison, considered endangered in 2000 and vulnerable in 2008 (Olech and IUCN SSC Bison Specialist Group 2008), was fundamentally based on a set of activities including population number monitoring, supplementary feeding and culling (Pucek 2004). Although this set of activities was with time supplemented with additional ones (like health monitoring, including research on diseases and parasites), the core actions were inherited from the traditional nineteenth-century management practices. Recent scientific surveys show that these measures resulted in slow adaptation of European bison to contemporary European forest ecosystems (Pucek 2004), and had a negative impact on bison health and overall ecology of the species (Radwan et al. 2010; Kowalczyk et al. 2011; Kerley et al. 2012; KołodziejSobocińska et al. 2016). Recent evidence recognised European bison as refugee species confined to suboptimal or marginal forest habitats (Kerley et al. 2012; Bocherens et al. 2015) and indicated the need for the development of management interventions based on pre-refugee ecology and increasing scientific evidence (Kerley et al. 2012; Cromsigt et al. 2012).

In the ancient times, bison range covered Central, SouthEastern and Eastern Europe but since then it shrunk dramatically (Benecke 2005; Onar et al. 2017). By the end of the eighteenth century, only two populations survived-in Białowieża Primeval Forest (BPF) and the Caucasus Mountains (Pucek 2004; Samojlik 2005; Samojlik and Jędrzejewska 2010). The persistence of the European bison in BPF resulted from protection of both the forest as the royal hunting ground and the bison as a key hunting species (Samojlik and Jędrzejewska 2010). Until 1795, apart from hunting, BPF was a subject to traditional, multi-functional utilisation, which was based on royal access rights. The most widespread and long-lasting right was haymaking, which created attractive foraging habitats for European bison in the growing season and supplemented them with fodder in winter in the form of haystacks (Samojlik and Jędrzejewska 2010). This unintentional system of additional bison feeding was then turned into a legally obligatory method of management in 1700 and since then bison were regularly supplemented with hay by forest guards. Additionally, at least since 1783, an annual winter counting of bison was carried out to monitor the population (Samojlik and Jędrzejewska 2010). Thanks to a well-established protection system (in the eighteenth century, BPF was guarded by well over 300 foresters, wardens, riflemen and beaters, Hedemann 1939) and predominance of non-destructive traditional ways of forest use, the forest remained almost undisturbed until the end of the eighteenth century (Samojlik et al. 2013) with bison population numbering around 300 (Samojlik and Jędrzejewska 2010). Since 1795, when Poland lost its independence, BPF fell under Russian rule and was not protected for several years, jeopardizing the fate of the forest and its largest dweller. Fortunately, uncontrolled forest exploitation and, especially, the uncertain fate of one of two remaining bison populations forced the Russian Tsar Alexander I to resume protection of the BPF in 1802, including bison counts (in 1809; Karcov 1903) and the provision of hay. Simultaneously, all hunts in BPF were 
prohibited (Karcov 1903; Hedemann 1939). From that point on, there is an evidence of several management and conservation measures employed by the forest administration, all focusing on different ideas of preserving, promoting and at the same time utilizing Białowieża's most valuable species. In the nineteenth century, bison conservation was one of the most important driving factors of the management of BPF, influencing decisions on timber production (Karcov 1903), types of non-timber utilization allowed and cattle pasturing in the forest (Samojlik et al. 2016).

Data on hay production is available from 1868 (Karcov 1903), but several remarks in the nineteenth-century literature suggested that additional feeding was introduced much earlier (Brincken 1826; Eichwald 1830; Jarocki 1830) and that it could have had pronounced effect on bison population. Publications on BPF's bison indicated that in the course of the nineteenth century, European bison numbers increased dramatically (up to 1898) with an equally drastic decline (Jędrzejewska et al. 1997). Already in the late nineteenth century, there were attempts to explain this dynamics (Büchner 1895; Ruzkii 1898; Karcov 1903). Some authors saw the increase of population as a plausible outcome of the lack of predation or competition from other ungulates, assuming the latter played a decisive role in population decline (Krasińska and Krasiński 2013). A multi-factor analysis of factors shaping the densities of ungulate populations in BPF showed that the rate of increase of the European bison population was highly dependent upon political stability, which in turn influenced the conservation (or lack of thereof) of bison (Jędrzejewska et al. 1997). Mysterud et al. (2007), on the other hand, analysed the recent variation in vital rates of bison population in 1952-2002, showing that climatic conditions and masting affected recruitment rates.

The current decision-making concerning bison is still influenced by century-old traditions (e.g. contemporary supplementary winter feeding of bison has not radically changed since 1700s), which possibly has an important influence on the population's condition and perspectives (e.g. higher parasite transmission in winter aggregations around fixed feeding sites; Pyziel et al. 2011; KołodziejSobocińska et al. 2016). The data on past management of the species in BPF could therefore provide managers of the population with accurate information on past management actions and their effects on bison population as well as insights as to the evidence on which this management was based. To do so, we collected both published and archival information on bison population dynamics and management practices in BPF in the nineteenth and beginning of the twentieth century. In the case of BPF's European bison, the historical data (1808-1915) document not only the abundance of animals, but also conservation measures taken by managers. Therefore, in our study, we used archival sources (see Appendix) which previously did not attract the attention of zoologists together with published literature to:

(1). collect newly identified archival data on bison abundance and update current knowledge on population dynamics in BPF in the nineteenth and the beginning of twentieth century;

(2). collect and analyse the new archival data on past management activities focused on bison protection;

(3). identify anthropogenic and environmental factors that might have affected bison numbers in BPF in the nineteenth and the beginning of twentieth century;

(4). on the basis of archival sources, evaluate the reliability of the published historical data on European bison abundance in BPF;

(5). discuss the importance of the findings for current management practices of European bison.

\section{Study area and methods}

\section{Study area}

Our study covered the entire Białowieża Primeval Forest (BPF), an area of about $1500 \mathrm{~km}^{2}$ regarded as one of the best preserved lowland temperate European forests. The forest originated after the last glaciation and in the last 12,000 years; its continuity as an area covered with dense, closed-canopy vegetation has never been significantly disrupted, although traces of human presence are dated as early as the late Neolithic or the early Bronze Age. All settlement waves distinguished in palynological and archaeological records in the Holocene were characterized by low agricultural activity and relatively low impact on forest cover (Latałowa et al. 2016). Large parts of BPF have been never modified, clear-cut or replanted, despite the long history of human-forest interactions (Latałowa et al. 2015). In the fourteenth-eighteenth centuries, the BPF served as a royal hunting ground, protected against logging and poaching but at the same time used for haymaking, forest beekeeping, fishing in forest rivers or pasturing cattle. Since the seventeenth century, potash, wood tar and charcoal production were also introduced - despite these uses being heavily wood-demanding, at the end of the eighteenth century, almost $60 \%$ of the forest was devoid of any traces of anthropogenic impact (Samojlik et al. 2013). Analysis of historical maps showed that between 1793 and 1900 , forest cover decreased from 81.3 to $73 \%$ with a simultaneous increase in meadow and shrub area from 8.1 to $17.3 \%$ (Mikusińska et al. 2013). The available information on forest composition in the nineteenth century shows that the forest was more coniferous compared to its contemporary state-in 1826, conifers were estimated to constitute approx. Eighty 
percent of the forest (Brincken 1826), in 1863, 60\% (Bobrovskii 1863) and at the end of the century, 59.6\% (Genko 1902-1903). In the contemporary BPF, now divided between Poland (ca. $600 \mathrm{~km}^{2}$ ) and Belarus (ca. $900 \mathrm{~km}^{2}$ ), coniferous (dominated by Pinus sylvestris and Picea abies) and mixed coniferous forests (Pinus sylvestris, Picea abies and Quercus robur) cover $62 \%$ of the entire BPF (Jędrzejewska and Jędrzejewski 1998). Deciduous (Quercus robur, Tilia cordata and Carpinus betulus) and mixed deciduous (Picea abies, Quercus robur, Tilia cordata and Carpinus betulus) forests cover $10 \%$, and $18 \%$ of the area is dominated by streamside alder-ash and wet black alder bog forest (Alnus glutinosa and Fraxinus excelsior) (Jędrzejewska and Jędrzejewski 1998).

The reconstruction of the climate in the region of BPF in the nineteenth century shows colder (1780-1820) and a warmer (1820-1870) periods than the average yearly temperature (Jędrzejewska and Jędrzejewski 1998), the first being probably the last remnant of the Little Ice Age climate cooling (Wanner et al. 2008). The coldest part of the Little Ice Age, the Maunder Minimum (1645-1715), potentially had a limiting effect on BPF's ungulates. Although there is no evidence linking climate change with fluctuation in animal populations, it was probably this period when red deer (Cervus elaphus) went extinct (or was exterminated) in BPF (Jędrzejewska et al. 1997).

In the beginning of the nineteenth century, the BPF harboured four species of ungulates: European bison, moose Alces alces, roe deer Capreolus capreolus and wild boar Sus scrofa. Red deer was reintroduced to a closed animal reserve in 1865 together with several Siberian roe deer Capreolus pygargus and fallow deer Dama dama. Animals were released into the forest in winter 1891-1892, and around that period, the administration of BPF started to introduce red, fallow and roe deer obtained from different parts of Europe and the Russian Empire (RSHA 1891-93, 1894-95, 1896-98, 1904-1907, 1912-1914; Matosiuk et al. 2014). In the beginning of 1910s, growing number of those three species started to raise concerns in the forest administration (in 1913, there were 5.5 thousand red deer, 4.5 thousand roe deer and over 1 thousand fallow deer; RSHA 1912-14, Jędrzejewska et al. 1997). At the turn of the nineteenth and twentieth century, BPF was inhabited by six ungulate species (counting both roe deer as one species). One more ungulate (albeit not wild) was occasionally present in the forest - in the nineteenth and twentieth centuries, domestic cattle were pastured on forest meadows, usually close to the villages (Jedrzejewska et al. 1997; Samojlik et al. 2016).

Throughout the most of the nineteenth century, all carnivores were persecuted in BPF, which had the greatest impact on large predators i.e. wolf Canis lupus, lynx Lynx lynx and especially brown bear Ursus arctos which was exterminated around 1878 (Genko 1902-1903; Karcov 1903; Jędrzejewska et al. 1997; Jędrzejewska and Jędrzejewski 1998; Samojlik et al. 2018).

In 2017, there were over 1214 European bison living in BPF (both, in Polish and Belarussian parts), out of total 5036 world's free-living population (Raczyński 2018). Both populations in BPF are separated by a $2.5-\mathrm{m}$-high fence erected along Polish-Belarussian border in 1981 (Kowalczyk et al. 2011). European bison management practices in BPF incorporate annual winter counting, supplementary winter feeding with hay and silage, occasionally beetroots and culling of selected animals (mainly injured or ill) (Krasińska and Krasiński 2013).

\section{Sources of data}

In search of historical data on European bison management in the nineteenth and the beginning of twentieth century, we conducted a thorough survey of the reports published in the nineteenth and twentieth century, finding new data. We also undertook a survey of Belarusian and Russian archives: Russian State Historical Archive in St. Petersburg (RSHA), National Historical Archives of Belarus in Grodno (NHABG); Central State Historical Archive in St. Petersburg (CSHAStPb), St. Petersburg Branch of the Archive of the Russian Academy of Sciences (SPBARAS), State Archive of the Russian Federation in Moscow (SARF) and Russian State Naval Archive in St. Petersburg (RSNAStPb).

Bison were counted annually since approximately 1802 (Hedemann 1931), although first known reports on bison numbers in the Russian period come from 1809 (Karcov 1903; RSHA 1813-1827). The data on bison numbers presented in this paper in total covered the period 1809-1915 and came both from already published works (Karcov 1903; Wróblewski 1927; Krasińska and Krasiński 2013) and unpublished archival sources (listed in Online Resource 1).

Karcov (1903) is the most important source of data on European bison numbers among published materials. He compiled data from all earlier publications and added unpublished data from archival documents he had access to, yet, as a diligent amateur, he did not cite particular archival documents. In many cases, we managed to find documents attesting the reliability of numeric data given by Karcov. In Online Resource 1, numbers from Karcov (period 1809-1902), Wróblewski (period 1903-1908) and Krasińska and Krasiński (for year 1914) are given in the first column, and whenever we were able to confirm them with archival data, they are given in bold. If the archival sources contained a number different from the one published, we presented this in the column "Alternative No of bison".

We also verified and supplemented Karcov's information on yearly bison offtake i.e. animals captured alive, killed during official hunts or poached with data from archival and 
published sources (see the entire list of sources in Online Resource 1).

The information on the amount of hay and other crops (clover, oats and tubers in 1898-1915) provided for bison for winter feed was extracted from the lists presented in Eichwald (1830), Karcov (1903) and Wróblewski (1927) and substantially supplemented with newly found unpublished archival sources (see the entire list of sources in Online Resource 1). To standardize the data on the amount of fodder, original units were recalculated to tonnes using the following conversions: 1 pound $=0.409 \mathrm{~kg}, 1$ pood $=40$ pounds $=16.38 \mathrm{~kg}, 1 \mathrm{cart}=25 \operatorname{poods}=409.5 \mathrm{~kg}$ (Daszkiewicz et al. 2004; Cardarelli 2003).

\section{Results - historical management of bison}

Based on historical changes of policy towards bison, we discriminated three periods of European bison management:

(1) 1795-1859: Starting with the third partition of Poland, and ending just before the first Tsar's hunt in BPF that resulted in shift in policy towards the forest and bison. In this period, three phases of political turmoil potentially resulting in uncontrolled exploitation of bison population can be discriminated: 1795-1802 (from the third partition until the return of legal protection of bison), 1812 (Napoleon's invasion of Russia) and 1830-1831 (Polish national insurrection, November Uprising).

(2) 1860-1888: The starting point of this period is the first Tsar's hunt in BPF in 1860. The hunt marked a turn in Tsars' attitude towards BPF. So far, the imperial family was not interested in the forest, but after the hunt, an idea of turning it into an imperial game reserve was born. Since 1860 , a change from timber- to game-oriented management was implemented. The fact that BPF held Europe's last free-ranging population of lowland European bison had a crucial impact on that shift. The period ended with the fruition of long-lasting efforts of turning the BPF into a hunting ground and transferring it to Tsars' private property. A phase of political turmoil, potentially increasing uncontrolled poaching occurred between 1863 and 1864 (Polish national insurrection, January Uprising);

(3) 1889-1915: In 1888, the status of BPF changed-the Romanov family bought out the BPF, together with the neighbouring Świsłocz Forest from state domains (in exchange for an equal area in the other provinces of the Russian Empire). In 1889, two separate forest and game administration were installed in BPF, which was from that point on treated as a distinct administrative unit. This change was motivated by the "need to fundamentally reshape the management of the (...) richest hunting ground in the world" (Karcov 1903), to improve the conservation of European bison, organize further royal hunts and build a hunting palace in Białowieża (Genko 1902-1903). New forest management undertook the goal of "preserving the doomed species of European bison" (Golenko 1935). This period ended after the outbreak of World War I and the forest occupation by the German army. This event marked the beginning of massive timber exploitation, and led to the bison extirpation by 1919 (Jędrzejewska et al. 1997).

Throughout the nineteenth century, European bison management was based on six principles: (1) population monitoring, (2) conservation of bison for royal and high-ranked hunts and protection from poaching, (3) supplementary feeding, (4) eradication of predators, (5) mitigation of bison migrations out of BPF, (6) habitat changes for bison conservation.

\section{Population monitoring}

The method used in monitoring of bison numbers, counting tracks after fresh snowfall, was described in 1840s as sufficient, and any drops in numbers were attributed to errors in counting or snow too shallow for distinguishing tracks. This was based on the fact that foresters estimated yearly increase of at least 30 calves, with no more than 10 dead bison reported each year (RSHA 1840-1849). In the second period, although the management plan stated that bison should be counted twice each winter-after the first and the last snowfall (NHABG 1861) - the available data confirms that only one count per year was performed. In the third period, a new approach to bison counting, based on three complementary methods, was employed. The first method was based on traditional winter counts, which engaged large numbers of people in a complicated logistical task. Counting was conducted on the day after fresh snowfall - no fodder was put out then, so animals dispersed through the forest in search for food. All guards were obliged to start counting tracks at the same time, and noting all animals entering and exiting the range which each guard was responsible for. Numbers from all guards were collected and collated, paying attention to counted animals passing from one range to another (RSHA 1899-1903). The second method was based on counting done in feeding points and the third, on year-round observations by guards. From 1900 on, three different numbers of bison were produced and then unified by the head of the game administration (RSHA 1899-1903).

Bison numbers in the first period ranged from 350 to 1898 , and an average yearly increase amounted to $3.03 \pm 1.16 \%$ (range -24.45 to 17.2 ). In the second period, bison numbers ranged from 384 to 1575 , and an average yearly increase amounted to $-3.04 \pm 1.99 \%$ (range -35.1 to 12.8 ). In the third period, bison numbers ranged from 380 to 747 , and an average yearly increase amounted to $2.69 \pm 1.37 \%$ (range -11 to 18.9) (Online Resource 1, Fig. 1). 


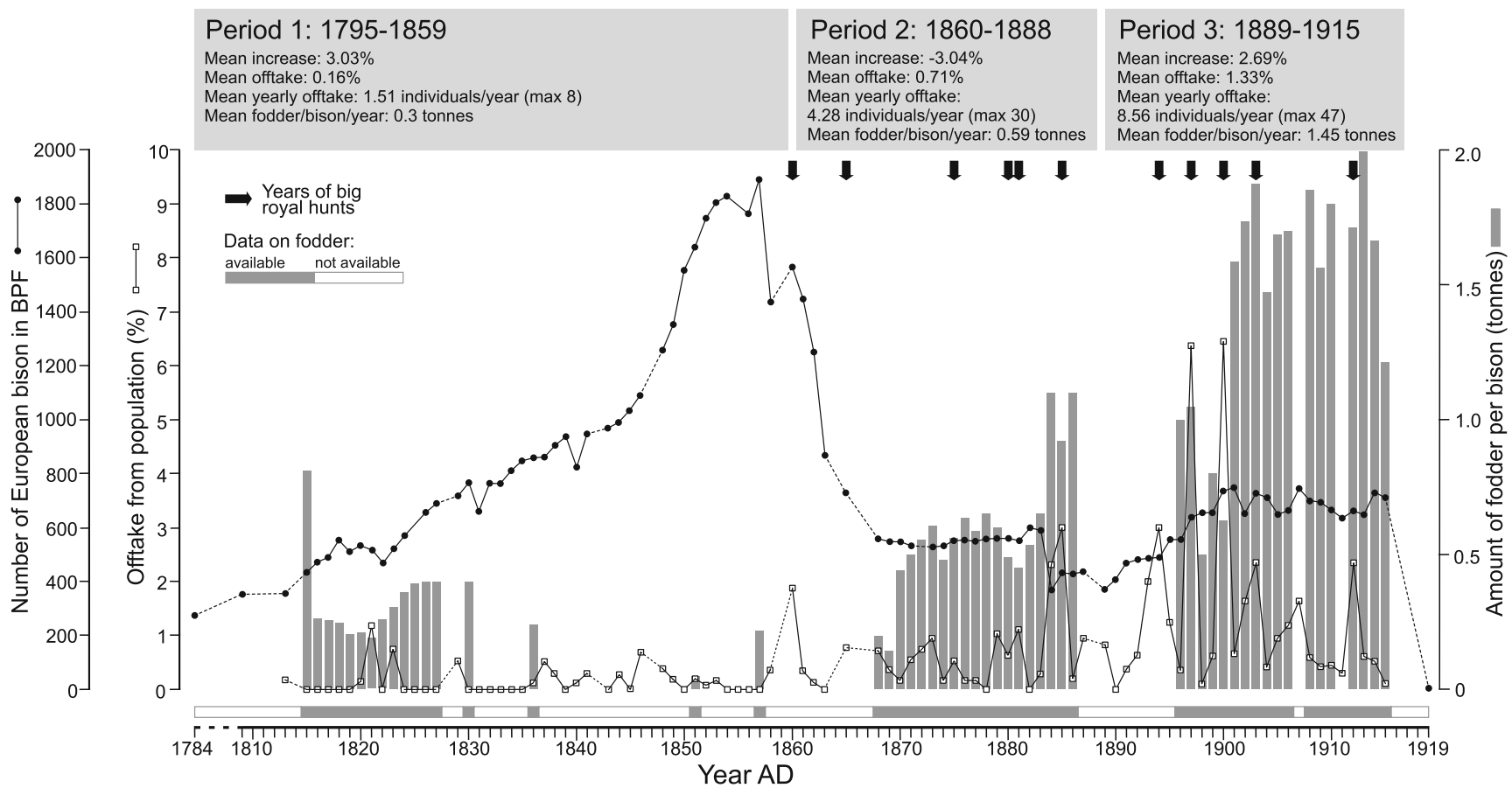

Fig. 1 Three periods of European bison management in Białowieża Primeval Forest in 1795-1915, with number of bison, anthropogenic offtake from population (with the biggest royal hunts indicated) and amount of supplementary fodder for bison (sources of data listed in Online Resource 1)

\section{Royal hunts and protection from poaching}

The topics of official hunts, capturing live animals for the zoos and hunting reserves (Samojlik et al. 2017; Fedotova et al. 2018) and poaching are on the opposite side of the scale from the legal point of view, yet they result in the same: removal of bison from the forest. Since the Tsar's first hunt in 1860, several actions were taken to enable more frequent royal hunts, including creation of a permanent animal enclosure, prohibition of all other hunts, introduction of fallow deer and reintroduction of red deer. All this led to six royal hunts in the second period-in years 1860, 1875, 1880, 1881 and 1885 (see Fig. 1) (Karcov 1903). In the third period, a new model of game management, based on promoting game species (reintroduction of red deer, introduction of fallow deer, additional feeding of ungulates), clearing compartment lines and building hunting roads in the forest (measuring in total, respectively, 750 and $530 \mathrm{~km}$ ) enabled five big imperial hunts (in years 1894, 1897, 1900, 1903, 1912, see Fig. 1) and several smaller hunts by members of royal family and more productive hunts, e.g. 680 animals (including 45 European bison) killed in 1900 (Karcov 1903; RSHA 1894-1903).

The total reported anthropogenic offtake in the first period (1795-1859) amounted to 77 animals: 71 bison shot and captured alive, and six recorded cases of poaching-i.e. 1.51 bison a year $(0.16 \%$ of the population). In the second period
(1860-1888), 86 bison were hunted or captured alive, and 38 were poached (Karcov 1903), thus anthropogenic offtake amounted to 124 bison, and yearly offtake averaged at 4.28 animals $(0.71 \%$ of the population). In the third period (18891915), 152 bison were killed and 33 animals were captured alive, and there were 46 bison poached-anthropogenic offtake amounted to 231 bison, with mean yearly offtake at 8.56 animals (1.33\% of the population) (Online Resource 1, Fig. 1). In general, archival data corrected the numbers given by previous published works, e.g. anthropogenic offtake in Karcov (1903) amounted to 71, 83 and 140 bison in the three respective periods.

\section{Supplementary feeding}

In the first period, beaters (a category of forest servicemen dating back to the Polish-Lithuanian period, recruited from local peasants) had the duty to scythe forest meadows and prepare hay for winter feeding of bison, similarly to the system of additional winter feeding dating back to 1700s (Samojlik and Jẹdrzejewska 2010). In the second period, hay for bison winter feeding was prepared by 102 beater families from four villages located on the southern and eastern border of the forest (RSHA 18161825 ). Some of the hay was traditionally left on meadows, but the rest was transported to 4 barns for fodder, 8 wooden roofs for storage and 10 feeding racks (Karcov 1903; RSHA 1889-1894). In the third period, 
from 1895 , new feeding points were built, finally achieving 64 barns for fodder, 27 wooden roofs and 321 feeding racks in 1902 (Karcov 1903). Feeding in those spots was exercised for prolonged periods: from 166 days in 1895 to 202 days in 1905 (sources listed in Online Resource 1). From 1895, reflecting the extension of the feeding period and increase of fodder rations, the forest administration started to buy clover, hay bales and tubers (in addition to hay produced for bison in the forest) from areas beyond the forest. In addition, meadows inside the forest were kept open for the purposes of bison feeding.

In the first period, the average yearly supplement of hay amounted to $197 \pm 13 \mathrm{t}(0.31 \mathrm{t}$ of hay per bison), ranging from 89 to 409 t. In the second period, an average yearly supplement of hay amounted to over $306 \pm 18 \mathrm{t}(0.59 \mathrm{t}$ of hay per bison), ranging from 75 to $470 \mathrm{t}$ in different years. In the third period, an average yearly supplement of hay amounted to over $490 \pm 28 \mathrm{t}$ ( $0.73 \mathrm{t}$ of hay per bison), ranging from 167 to $713 \mathrm{t}$. Apart from hay, in the period 1898-1915, bison were provided with other types of fodder: clover, oat and root crops (on average, $551 \mathrm{t}$ yearly, ranging from 123 to $855 \mathrm{t}$, and on average amounting to $0.81 \mathrm{t}$ per bison). The total supplementation with all fodder summed up to $989 \mathrm{t}$ per year and $1.45 \mathrm{t}$ of fodder per bison annually (Online Resource 1, Fig. 1). The majority of this data is new-previously only the amount of hay provided for bison in the period 1868-1886 was available (Karcov 1903), with no information on the first and third periods.

\section{Eradication of predators}

The policy of predator eradication to protect bison was introduced to BPF immediately after its acquisition by the Russian Empire. All forest officials were allowed to hunt for brown bears, wolves, lynx, foxes, polecats and other smaller predators for an annual tax (all those were fur animals with significant market value). In 1821, hunts were prohibited as harmful for European bison, but in later in the 1820 s they were renewed each time a bear, wolf or lynx were spotted (RSHA 1827-1833). After a few sightings of European bison being attacked by bears, they became the main target of ant-predator policy (Karcov 1903, RSHA 1840-1849), resulting in their eventual eradication (Samojlik et al. 2018). At the same time, the annual depredation of bison by wolves was estimated as not higher than eight animals (RSHA 1840-1849); nevertheless, the eradication policy continued with the addition of wolf and lynx poisoning using strychnine (RSHA 1839-1842). In the late 1840s, prizes were introduced for killed wolves in western and southern provinces of the Empire in connection with complaints of wolves attacking livestock. It is difficult to estimate how effective these measures were; nevertheless, in the Grodno Province rewards for hundreds of wolves were paid annually (NHABG 1846-1850, 1851). In 1869, it was still reported that a high number of bison calves was killed by predators, especially wolves, and forest personnel was accused of ineffective eradication of predators (NHABG 1869), yet according to Karcov (1903) in the second period only 19 bison were killed by wolves, and 4 by bears. Eradication of predators was still in effect in the third period (RSHA 1889, 1898-1899, 1910-1911). Strychnine use was prohibited, as it became more dangerous to wild boar and dogs of forest guards (mainly dachshund used by riflemen to dig out badgers and foxes) than to predators (Karcov 1903).

\section{Mitigation of bison migrations}

In the first period, a common notion was that bison have survived in BPF and are not present anywhere else on the continent because of a single or several plants characteristic only for Białowieża's woods. Although the Polish botanist, Stanisław Batys Górski established already in 1829 that among grasses eaten by bison, none were endemic to BPF (Daszkiewicz et al. 2004), this notion survived long into the nineteenth century. Additionally, it was believed that felling trees and other work that required the presence of larger number of people in the forest scared the bison away. To prevent this kind of disturbance, any kind of tree felling in BPF was prohibited in 1820 (RSHA 1813-1827). This conservation status was partially suspended in 1839-1841, when timber for shipbuilding was extracted from the forest (RSNAStPb 1839-1840). In response, according to some observations, European bison started to move from BPF to adjacent forests, which was allegedly not observed previously (RSHA 1840 1849). On the contrary, other observations suggested that European bison quickly adapted to the presence of loggers and eagerly fed on saplings and bark of felled trees (RSHA 1840-1849). In the second period, the new management plan of 1877 reintroduced timber production only in the outer part of the forest: it was believed that European bison lived mostly in the central part. In 1875, for the purposes of bison protection, a fence was built to divide the outer parts of the forest not frequented by bison (which was exploited for timber) and the inner part (which was excluded from exploitation), where bison were present. Reportedly, the fence survived only until 1885 (Genko 1902-1903). The third period started with several commissions assessing the state and possible exploitation level of BPF. It resulted in short phases of felling (1888-1890, 1903-1905, 1908-1913) mixed with prolonged periods of exploitation of dead wood only, with very limited selective cutting of the living trees (Genko 1902-1903, RSHA 1908-1912; Więcko 1984). 


\section{Habitat changes for bison conservation}

Different forms of land management opening the forest, mainly scything forest meadows for the purposes of additional bison feeding, were practiced in BPF throughout the nineteenth century. Unfortunately, precise data on the area of meadows utilized in this way is available only for the end of the third period and comes from 1911 forest taxation (RSHA 1912). The source lists different forms of land use beneficial to bison: 2758 ha (i.e. $2.6 \%$ of the entire BPF area, calculated at $104112 \mathrm{ha})$ under haymaking for bison, 577 ha $(0.6 \%$ of the BPF) of meadows for animal feeding planted with species valuable for game (Karcov 1903), 4884 ha (4.7\% of the BPF area) inside and on the border of the forest under pasturing and haymaking for purposes of forest guards and local dwellers (RSHA 1912). Overall, in the beginning of the twentieth century, $7.9 \%$ of BPF was utilized in a way potentially beneficial to European bison.

Additionally, for at least 2 years in a row the forest administration ordered to destroy spruce underwood in BPF to improve the forage conditions for bison: on an area of over 500 ha in 1877, and nearly 90 ha in 1878 (NHABG 1878, NHABG 1879).

\section{Discussion}

\section{Drivers of European bison population fluctuations in the nineteenth-beginning of the twentieth century}

Previous analysis by Jędrzejewska et al. (1997) showed that the bison increase rate was mainly affected by political instability, bison density in the forest along with the density of other ungulates, whereas large predators were found to have no impact on bison population. Based on the new data it is possible to hypothesise on other factors potentially driving the species' population dynamics in the nineteenth-beginning of twentieth century. The supplementary feeding and habitat changes (i.e. opening of the forest) can be ascribed to the group of factors supporting the growth of bison population, whereas the anthropogenic offtake can be seen as the main limiting factor-strong enough to level the intensive additional feeding in the third period. Predators seem to have little to none impact on bison population.

The first period witnessed the greatest increase of the absolute values of bison number, from 350 to the maximum of 1898 , which provoked a lot of discussion on the credibility of annual counts in the mid-nineteenth century (see the section below). Lack of data on additional feeding in the phase of the largest increase of bison population does not allow any conclusions regarding the factors responsible for this pattern. Factors that could partially explain this dynamic include the low anthropogenic offtake (1.51 individuals per year), relatively low level of forest exploitation and low level of competition from other ungulates. The latter conclusion can be drawn from the fact that the moose population has never reached significant numbers in forested areas of BPF (Jędrzejewska et al. 1997), and red deer was released into the forest only in the 1890s (Karcov 1903). Also, although domestic cattle pasturing in BPF was not yet strictly regulated, cattle and herders presence was most probably restricted to the areas near villages on the border of the forest (Samojlik et al. 2016).

Was this large increase plausible from the ecological point of view? Sex ratio in the contemporary bison population if fairly even, and bison start reproducing at the approximate age of four (Krasińska and Krasiński 2013). In the wild, bison females have calves usually every second year, whereas in captivity (but also probably in the wild when food conditions are favourable)-yearly (Krasińska and Krasiński 2013). Mysterud et al. (2007) calculated the recruitment rate of European bison in BPF in the period 1961-2001 based on the collected data (for the population $>250$ individuals). The increase rate of the population size varied depending on the severity of winter, temperature in May and masting of oaksfrom 1.049 in the worst, to 1.152 in the best case scenario. The rise of the bison population leading to the peak number of 1898 individuals in the year 1857, even with its most significant increases (e.g. in 1850, with an increase of 206 bison), still fits into the variability of demographic rates calculated by Mysterud et al. (2007). It is then the drop in population numbers that is difficult to explain just by looking at the numbers of bison removed from population or dead by natural causes.

In the second period, the population decreased at the mean yearly rate of $-3.04 \%$, but the main and most rapid decline occurred in the beginning of this period, in 1860 1868 (falling from 1575 to 559 individuals, over a thousand bison lost in 9 years), stabilizing thereafter (Fig. 1). The higher offtake of 4.28 individuals per year is not enough to explain this drop in numbers, but there was probably a large number of bison poached during the January Uprising of 1863-1864 that were not reportedbig enough to offset the effect of increased additional feeding ( $0.59 \mathrm{t}$ of hay per bison annually). Such an effect is especially visible in 1884-1886, when the high number of hunted and poached animals coincided with an increase in supplementary feeding (Online Resource 1, Fig. 1).

In the third period, the population increased at a mean rate of $2.69 \%$, with the most significant rise in the period 1889-1901 (from 380 to 747 individuals). This rapid rise coincided with two biggest hunts for bison in 1897 and 1900. We hypothesise that the higher exploitation of the bison was most probably levelled by a drastic increase in the amount of additional fodder offered to bison (Fig. 1). 
Other factor that could have supported the rise in bison numbers was the opening of the forest. Analysis of archival maps of BPF (Mikusińska et al. 2013) showed rapid increase of the area of meadows and shrubs throughout the period $1830-1900$ (from $10.2 \%$ in 1830 to $17.2 \%$ in 1900), but the historical data suggests that it was especially the third period when forest was opened as a consequence of European bison management policy, i.e. scything meadows inside the forest for haymaking, cultivating glades for the purposes of bison feeding, and creating hundreds of feeding points with barns for fodder, wooden roofs and feeding racks. This could have created more suitable habitats for bison adapted to open and mixed habitats (Mendoza and Palmqvist 2008; Bocherens et al. 2015) and confined to forest habitats due to anthropogenic pressure during the Neolith (Kerley et al. 2012; HofmanKamińska et al. 2018, 2019). In conjunction with areas utilized by forest personnel and local peasants in a similar manner, the open areas potentially beneficial for bison covered $7.3 \%$ of BPF. According to the refugee species hypothesis (Kerley et al. 2012), supported by recent isotopic analyses (Bocherens et al. 2015; Hofman-Kamińska et al. 2018), European bison in early Holocene utilized a relatively open tundra-like environment and it was only anthropogenic pressure that drove them into forested and less accessible (for humans) habitats. Anthropogenic opening of the forest in the nineteenth century, together with supplementary feeding can, in this respect, be seen as factors mitigating the limiting impact of confinement to forest habitat and thereby increasing bison fitness and population densities (Kerley et al. 2012). The relative low numbers of bison at the end of the eighteenth century (284), after 400 years of royal protection, supports the perspective on species' poor adaptation to dense, closedcanopy forests, which BPF was at that time (Samojlik et al. 2013). The increase of winter feeding and opening of forest habitats allowed for the population growth, and even compensated the higher anthropogenic offtake in the third period.

\section{Reliability of historical data on bison numbers}

One of the biggest issues connected with historical information on animal abundance is the credibility of the data - in this case, annual bison counts in BPF. Constant year-to-year increase in European bison numbers (1823-1857) raise questions if the data reflects actual population dynamics or is it an artefact of non-reliable data collection, or data manipulated by managers under pressure to report an increase? In the first period described above, there was already pressure on forest personnel to produce expected results, i.e. a rise in the number of bison. After 2 years in a row when bison numbers dropped (1821 and 1822), wardens responsible for bison counting were officially reprimanded by the senior forester of the Grodno province for "incorrect" calculations (RSHA 1813-1827). After this incident, in each of the subsequent seven annual counts, bison numbers increased (Online Resource 1). From 1883 , bison counting was conducted under the personal supervision of foresters, leading to a significant drop in resultsfrom 592 reported in 1883 to 384 in 1884 and 433 in 1885 , "close to numbers from 1820 s, when there were up to 500 bison in the forest" (RSHA 1886). The reliability of past data on bison numbers in BPF was a matter of interest, especially connected with the ongoing discussion on possible bison degeneration and inevitable extinction (RSHA 1886). There is no evidence of direct data manipulation, but some curious inconsistencies in historical sources, for example the official note on bison protective measures from 1869 mentions the year 1855 as the moment when bison population in BPF peaked with 1824 animals, and from that point on it declined (NHABG 1869). The year 1857 reported by Karcov (1903) and others as the period with highest bison number (1898 animals) is not mentioned. Since the author of the document, Karl Stralborn, was the official administrator of the entire forest, it is hardly possible that he did not have data for year 1857. Furthermore, the author explicitly states that counting methods were unreliable in previous periods, as explained by local foresters asked about drop in reported bison numbers in 1858 (NHABG 1869).

In the second period, those controversies continued-in 1886 report (RSHA 1886), all bison numbers from the period before 1883 are put in doubt, as the method (bison counting conducted by beaters who reported the number to guards, who, in turn, reported them to the forester that prepared the official report) seemed more like expression of forester's assumption than actual count of animals.

Despite all controversies connected with historical bison numbers, their analysis is still valuable. It shows a general pattern of factors supporting the growth of the bison population: additional feeding, opening of the forest and low anthropogenic offtake. Also an assumption can be made that in the third period the first two factors were able to compensate very high, compared to previous periods, offtake.

It is impossible to conclusively assess the credibility of bison counts in the nineteenth century as no documents directly connected with bison counting in the phase of population peak (1850s) were found during this study. It is quite possible that the case of bison as one of the most, if not the most charismatic species of the Old World followed what Monsarrat and Kerley (2018) described as bias in reporting of large mammals in written sources. Long-term occurrence records from South Africa were found to be strongly biased, i.e. species perceived as charismatic (evidenced by anecdotes from the historical literature) were much more often reported and described in historical datasets than their historical abundances would suggest. Species' charisma was the main reason 
behind this the taxonomic bias in long-term biodiversity datasets, impacting the representativeness of species in longterm conservation studies. Historical data is therefore at the same time very valuable in any ecological and conservation analysis, and susceptible to being misinterpreted if taken too directly and uncritically. On the other hand, careful analysis of the circumstances behind such information (authors and their background, period, addressee of the information, etc.) can reveal potential biases of historical datasets and enable their comprehensive use in environmental history studies (Monsarrat and Kerley 2018).

\section{What can current management and conservation of European bison learn from the nineteenth-century experience}

European bison was legally protected since the sixteenth century (Samojlik and Jędrzejewska 2010), which was not unique for animalia superiora, big game reserved for royal hunts. On the other hand, legal protection of a particular species was quite unique, especially in the nineteenth-century Russian Empire. Furthermore, the case of European bison in imperial BPF is an early and rare example of an endangered species deliberately managed using all available administrative means for the purposes of its conservation, predating any other endangered species management plans. Over a century of bison management under Russian administration (from Tsar Alexander's act of 1802 until the capture of BPF by the German army in 1915) offers several lessons for current management and conservation of the species.

The nineteenth-century management was not evidencebased in the modern sense (Apollonio et al. 2017). Neither recently discovered written sources, nor the literature of the subject contain any information on actual analysis of the basis or impact of applied means of bison management. All decisions concerning supplementary feeding, distribution of feeding points or especially hunting and live capturing of bison were based on personal experience of game managers. Furthermore, since the mid-nineteenth century, a common notion that bison was doomed to extinction despite all the efforts was apparent in the published literature and official documents, stating that bison suffer mainly because of predators, poachers and old, infertile males preventing young males from breeding (or literally breaking spines of young females they mount). Nevertheless, some of the methods of bison management employed nowadays are a simple continuation of the approach developed in the nineteenth century. The results of our work, in conjunction with latest research on European bison ecology and evolution, could inform current management objectives of the species:

(1) European bison should be managed with close consideration of scientific evidence of impact of management on bison, other species sharing the same habitat and the habitat, i.e. BPF, itself.

(2) Supplementary feeding of European bison was exercised in BPF in the nineteenth century, with the volume (and variety) of fodder increasing in each of the three described periods. In the second and third period such increase was especially visible (Fig. 1), yet it led to a limited rise of bison numbers. On the other hand, intensive feeding for prolonged periods could affect movement and behaviour patterns of animals (Selva et al. 2017). In the period 1896-1914, bison were fed on average for 187 days (sources listed in Online Resource 1). There is no data available on the time of supplementary feeding in the previous periods, yet it is safe to assume that bison were fed as long, as long hay was available. This has led to habituation of bison to human interference and creation of winter aggregations around feeding sites (Krasińska and Krasiński 2013) as also observed nowadays (Haidt et al. 2018). It can be speculated that higher concentration of bison in such points resulted in increased parasite transmission (Wróblewski 1927; Kołodziej-Sobocińska et al. 2016), which should be observed in contemporary management.

(3) Treating bison as a forest specialist and setting the management goal of keeping bison confined to the forested area proved to be a problem in the nineteenth century, and continues to be such nowadays. Current research shows that European bison was an open-area species driven by anthropogenic (hunting) pressure to seek refuge in vast forests of Central and Eastern Europe already in Mediaeval times (Samojlik and Jędrzejewska 2010; Kerley et al. 2012). Increase of the open areas within BPF in the second half of the nineteenth century was a factor that limited European bison utilization of the areas outside if the forest, but since then the forest's openness is constantly decreasing (from $17.2 \%$ in 1900 , through $14.4 \%$ in 1936, to $7.4 \%$ in 1999 ; Mikusińska et al. 2013). Bison now tend to move to open areas outside of BPF for prolonged periods of time (Hofman-Kamińska and Kowalczyk 2012; Kowalczyk et al. 2013). Management confining bison to sub-optimal forest habitats prevents the natural selection of the species and sustains its refugee status (Kerley et al. 2012).

\section{Conclusions}

The data we have collected for this paper extends beyond simple records of occurrence and presents a unique longterm assessment of management practices and their effectiveness. It is a rare occasion that a large mammal population received so much attention already at the beginning of the nineteenth century, with records of this attention still existing in the archives. The first conclusion of our 
research is that the management of European bison has not changed over the last two centuries, and continues to be driven by tradition rather than scientific evidence. To avoid repeating the nineteenth-century mistakes, the current management approach must turn to evidence-based model. Our research also supports the notion that historical data is invaluable when setting modern conservation goals, as only vast knowledge on ecological baselines and reference conditions can allow managers to avoid the "shifting baseline syndrome". Nevertheless, all historical data should be critically reviewed and verified before it can be put to use in creating modern conservation and management plans. Historical management of bison in BPF in the nineteenth century, despite being driven mainly by hunting goals and acting against natural selection, secured survival of the species. It is an example of a complex environmental management that led to preservation of both Białowieża Primeval Forest and the last remnant of legendary megafauna-European bison - to the beginning of the twentieth century. European bison acted as an "umbrella species" and thereby secured protection of the forest. Nevertheless, the increasing scientific evidence concerning the optimal bison habitats, its refugee species status and population requirements should be taken into account when planning current management of the species. The advantage of historical data, especially information on past management of species or habitats, is the opportunity to evaluate modern management activities in the light of experiences from the past - and avoid making mistakes that were already once made.

\section{Appendix. Archival sources}

(CSHAStPb) Central State Historical Archive in St. Petersburg. 1835-1839. On the command by headquarters of mining engineer corps concerning the bison skeleton prepared in the Vilnius Imperial Medical-Surgical Academy for the museum (F. 963, O. 1, No 4608, in Russian)

Museum für Naturkunde Berlin. 1834-1837. H. Lichtenstein's correspondence with S.I. Wiedemann (BbH 1-12, Mappe W III)

(NHABG) National Historical Archives of Belarus in Grodno. 1846-1850. On taking measures to the extermination of wolves in the Grodno province, (F. 1, O. 21. No. 260, in Russian)

(NHABG) National Historical Archives of Belarus in Grodno. 1847. On permission to kill three bison in Białowieża Forest to send pelts and skeletons to Hamburg and Paris museums (F. 1, O. 5, No 734, in Russian)

(NHABG) National Historical Archives of Belarus in Grodno. 1851. Reports from land courts on the number of killed wolves in Grodno province counties (F. 1, O. 29, No 687, in Russian)

(NHABG) National Historical Archives of Belarus in Grodno. 1861. Rules of European bison conservation (F. 1, O. 6, No 160, pp. 4-13, in Russian)

(NHABG) National Historical Archives of Belarus in Grodno. 1869. Note by the administrator of Białowieża Forest on the European bison protective measures (F. 108, O. 1, No 1, in Russian)

(NHABG) National Historical Archives of Belarus in Grodno. 1875. Statistical information about the Grodno Province in 1874 (F. 1, O. 15, No 143, in Russian)

(NHABG) National Historical Archives of Belarus in Grodno. 1876. Statistical information about the Grodno Province in 1875 (F. 1, O. 15, No 591, in Russian)

(NHABG) National Historical Archives of Belarus in Grodno. 1877. Statistical information about the Grodno Province in 1876 (F. 1, O. 15, No 965, in Russian)

(NHABG) National Historical Archives of Belarus in Grodno. 1878. Statistical information about the Grodno Province in 1877 (F. 1, O. 15, No 1343, in Russian)

(NHABG) National Historical Archives of Belarus in Grodno. 1879. Statistical information about the Grodno Province in 1878 (F. 1, O. 16, No 184, in Russian)

(NHABG) National Historical Archives of Belarus in Grodno. 1880. Statistical information about the Grodno Province in 1879 (F. 1, O. 16, No 591, in Russian)

(NHABG) National Historical Archives of Belarus in Grodno. 1881. Statistical information about the Grodno Province in 1880 (F. 1, O. 16, No 953, in Russian)

(NHABG) National Historical Archives of Belarus in Grodno. 1882. Statistical information about the Grodno Province in 1881 (F. 1, O. 16, No 1243, in Russian)

(NHABG) National Historical Archives of Belarus in Grodno. 1910. Materials on counting bison in Białowieża Forest and Świsłocz property (F. 108, O. 1, No 10, in Russian)

(RSHA) Russian State Historical Archive. 1813-1827. On bison present in Białowieża Forest in Grodno province (F. 379, O. 4, No 7, page 1-79, in Russian)

(RSHA) Russian State Historical Archive. 1816-1825. On bison migrating from Białowieża Forest to the forests of graf Tyszkiewicz (F. 379, O. 4, No 561, in Russian)

(RSHA) Russian State Historical Archive. 1827-1833 On shooting wolves in BPF (F. 1589, O. 3, No 107, in Russian)

(RSHA) Russian State Historical Archive. 1837. On Białowieża Forest (F. 379, O. 8, No 355, in Russian)

(RSHA) Russian State Historical Archive. 1839-1842. On the note of Grodno forester Brinkman on methods of wolf and fox poisoning (F. 1589, O. 3, No 38, in Russian)

(RSHA) Russian State Historical Archive, 1840-1849. On introducing proper forest management in Białowieża Forest (F. 387, O. 1, No 7057, 7058, 7059, in Russian) 
(RSHA) Russian State Historical Archive, 1843-1846. On samples of grasses eaten by European bison (F. 398, O. 7, No 2083, in Russian)

(RSHA) Russian State Historical Archive. 1853. Journal of the Special Forest Committee on the audit of Białowieża Forest by colonel Dlatovskii 31st January 1853 (F. 387, O. 25, No 9, pp. 43-62, in Russian)

(RSHA) Russian State Historical Archive. 1854. On the number of bison present in Białowieża Forest (F. 387, O. 2, No 20362, in Russian)

(RSHA) Russian State Historical Archive. 1858. On killing of a bison in BPF for Waldau Agronomic Institute (F. 387, O. 2, No 21767, in Russian)

(RSHA) Russian State Historical Archive. 1858-1860A. On delivery of bison pelts to Jena, Gessen, Dresden and Stockholm museums (F. 387, O. 2, No 21761, in Russian)

(RSHA) Russian State Historical Archive. 1858-1860B. On the hunt in Lisino training forestry district, (F. 387, O. 2, No 23064)

(RSHA) Russian State Historical Archive. 1861-1862. On delivering bison skeletons and pelts to five foreign princes and for museums and universities (F. 387, O. 2, No 23602, in Russian)

(RSHA) Russian State Historical Archive. 1886. Report of Rachmaninoff and the forestry expert Svetlov on Białowieża game reserve and the European bison (F. 515, O. 42, No 3416, pp. 126-150, in Russian)

(RSHA) Russian State Historical Archive. 1889. On taking measures to exterminate predators in BP (F. 515, O. 43, No 37 , in Russian)

(RSHA) Russian State Historical Archive. 1889-1894. On construction of feeding racks, cellars with granary, and fences in Białowieża menagerie and on other expenses for game reserve (F. 515, O. 42, No 2941, in Russian)

(RSHA) Russian State Historical Archive. 1891-1893. On expenses for game reserve in BPF, 1891-93 (F. 515, O. 42, No 2894, in Russian)

(RSHA) Russian State Historical Archive. 1894-1895. On expenses for game reserve in BPF, 1894-95 (F. 515, O. 42, No 3357, in Russian)

(RSHA) Russian State Historical Archive. 1894-1903. Lists of participants of the Imperial hunt in the BPF with its plans and results (F. 478, O. 3, No 2899, in Russian)

(RSHA) Russian State Historical Archive. 1896-1902. On expenses for game reserve in BPF in 1896 (F. 515, O. 42, No 4346, in Russian)

(RSHA) Russian State Historical Archive. 1896-1898. On expenses for game reserve in BPF in 1897 (F. 515, O. 42, No 3609, in Russian)

(RSHA) Russian State Historical Archive. 1898-1899. About rewards for exterminating predators in the BPF (F. 515 , O. 42, No 4004, in Russian)
(RSHA) Russian State Historical Archive. 1898-1908. On expenses for game reserve in BPF in 1899 (F. 515, O. 80, No 172, in Russian)

(RSHA) Russian State Historical Archive, 1899-1903. On expenses for game reserve in BPF in 1900 (F. 515, O. 42, No 4148 , in Russian)

(RSHA) Russian State Historical Archive. 1901-1904. On expenses for game reserve in BPF Forest in 1901 (F. 515, O. 42, No 4351, in Russian)

(RSHA) Russian State Historical Archive. 1901-1903. On expenses for game reserve in BPF in 1902 (F. 515, O. 42, No 4150, in Russian)

(RSHA) Russian State Historical Archive. 1902-1903. On expenses for game reserve in BPF in 1903 (F. 515, O. 42, No 4154, in Russian)

(RSHA) Russian State Historical Archive. 1903-1907. On expenses for game reserve in BPF in 1904 (F. 515, O. 42, No 4583, in Russian)

(RSHA) Russian State Historical Archive. 1904-1907. On expenses for game reserve in BPF in 1905 (F. 515, O. 42, No 4585, in Russian)

(RSHA) Russian State Historical Archive. 1905-1911. On expenses for game reserve in BPF in 1906 (F. 515, O. 80, No 406, in Russian)

(RSHA) Russian State Historical Archive. 1908-1912. Recapitulation from different listings drafted during the taxation of BPF 1908-1912 (F. 505, O. 67, No 1170, in Russian)

(RSHA) Russian State Historical Archive. 1909-1913. On expenses for game reserve in BPF in 1910 (F. 515, O. 80, No 662, in Russian)

(RSHA) Russian State Historical Archive. 1910-1911. About rewards for exterminating predators in the BPF (F. 515, O. 80, No 788, in Russian)

(RSHA) Russian State Historical Archive. 1911-1914. On expenses for game reserve in BPF in 1912 (F. 515, O. 80, No 897, in Russian)

(RSHA) Russian State Historical Archive. 1912. Explanation of forest management plans in BPF (F. 515, O. 87, No 822, in Russian)

(RSHA) Russian State Historical Archive. 1912-1914. On expenses for game reserve in BPF in 1913 (F. 515, O. 80, No 1068, in Russian)

(RSHA) Russian State Historical Archive. 1913-1915. On expenses for game reserve in BPF in 1914 (F. 515, O. 80, No 1194 , in Russian)

(RSHA) Russian State Historical Archive. 1915-1916. On animals dead from infectious diseases in BPF (F. 515, O. 80, No 1501 , in Russian)

(RSNAStPb) Russian State Naval Archive in St. Petersburg. 1839-1840. On misconducts during the process of felling and transporting shipbuilding wood from BPF (F. 410, O. 1 , No 800 , in Russian) 
(SARF) State Archive of the Russian Federation in Moscow. 1860. History of the aurochs or European bison in BPF (F. 728, O. 1, No 2620, in Russian)

(SPBARAS) St. Petersburg Branch of the Archive of the Russian Academy of Sciences. 1847-1848. On acquisition of stuffed European bison from BPF for Zoological Museum (F. 2, O. 1-1847, No 9, in Russian)

Open Access This article is distributed under the terms of the Creative Commons Attribution 4.0 International License (http:// creativecommons.org/licenses/by/4.0/), which permits unrestricted use, distribution, and reproduction in any medium, provided you give appropriate credit to the original author(s) and the source, provide a link to the Creative Commons license, and indicate if changes were made.

\section{References}

Apollonio M, Belkin VV, Borkowski J, Borodin OI, Borowik T, Cagnacci F, Danilkin AA, Danilov PI, Faybich A, Ferretti F, Gaillard JM, Hayward M, Heshtaut P, Heurich M, Hurynovich A, Kashtalyan A, Kerley GIH, Kjellander P, Kowalczyk R, Kozorez A, Matveytchuk A, Milner JM, Mysterud A, Ozolinšs J, Panchenko DV, Peters W, Podgórski T, Pokorny B, Rolandsen CM, Ruusila V, Schmidt K, Sipko TP, Veeroja R, Velihurau P, Yanuta G (2017) Challenges and science-based implications for modern management and conservation of European ungulate populations. Mammal Research 62:209-217

Armstrong CG, Shoemaker AC, McKechnie I, Ekblom A, Szabo P, Lane PJ et al (2017) Anthropological contributions to historical ecology: 50 questions, infinite prospects. PLoS One 12(2):e0171883. https:// doi.org/10.1371/journal.pone.0171883

Bilney RJ (2014) Poor historical data drive conservation complacency: the case of mammal decline in south-eastern Australian forests. Aust Ecol 39:875-886

Benecke N (2005) The Holocene distribution of European bison-the archaeozoological record. Munibe (Antropologia-Arkeologia) 57: 421-428

Bobrovskii P (1863) Materialy dla geografii i statistikii Rossii, sobraniye ofitserami generalnogo shtaba. Grodnenskaya Guberniya [Data for geography and statistics of Russia, collected by the officers of general staff. Grodno Province] St. Petersburg, Tipografiya Departamenta Generalnogo Shtaba (in Russian)

Bocherens H, Hofman-Kamińska E, Drucker DG, Schmölcke U, Kowalczyk R (2015) European Bison as a refugee species? Evidence from isotopic data on Early Holocene Bison and other large herbivores in northern Europe. PLoS One 10(2):e0115090. https://doi.org/10.1371/journal.pone.0115090

Bonebrake TC, Christensen J, Boggs CL, Ehrlich PR (2010) Population decline assessment, historical baselines, and conservation. Conserv Lett 3:371-378

Büchner E (1895) Das allmähliche Ausstorben des Wisents im Forste von Bjelowjesha - Zapiski Imp. Akademii Nauk 3(2):1-30

Brincken F (1826) Mémoire descriptif sur la forêt imperiale de Białowieża, en Lithuanie. Glücksberg, Warsaw

Cardarelli F (2003) Encyclopaedia of scientific units, weights and measures. Their SI equivalences and origins. Springer-Verlag, London, $p$ 845
Clavero M, Delibes M (2013) Using historical accounts to set conservation baselines: the case of Lynx species in Spain. Biodivers Conserv 22:1691-1702

Cromsigt J, Kerley G, Kowalczyk R (2012) The difficulty of using species distribution modelling for the conservation of refugee species the example of European bison. Divers Distrib 18:1253-1257

Daszkiewicz P, Jędrzejewska B, Samojlik T (2004) Puszcza Białowieska w pracach przyrodników 1721-1831 [Białowieża Primeval Forest in the writings of naturalists 1721-1831]. Wydawnictwo Naukowe Semper, Warszawa, $\mathrm{p} 185$ (in Polish)

Dean WRJ, Milton SJ (2003) Did the flora match the fauna? Acocks and historical changes in Karoo biota. S Afr J Bot 69(1):68-78

Eichwald K (1830) Naturhistorische Skizze von Lithuanien. Volhynien und Podolien, Vilnius

Fedotova A, Samojlik T, Daszkiewicz P (2018) Killing for museums: European bison as a museum exhibit. Centaurus 60(4). https://doi. org/10.1111/1600-0498.12194

Freese CH, Aune KE, Boyd DP, Derr JN, Forrest SC, Gates CC, Gogan PJP, Grassel SM, Halberd ND, Kunkel K, Redford KH (2007) Second chance for the plains bison. Biol Conserv 136:175-184

Genko N (1902-1903) Kharakteristika Belovezhskoi Pushchi i istoricheskiya o nei dannya [Characteristic of Białowieża Forest and historical information about it], 22nd edn. Lesnoi Zhurnal, St Petersburg, p 23 (in Russian)

Golenko M (1935) Museum of Białowieża Primeval Forest. Vozrozhdenie 3609:5 (in Russian)

Hacquebord L (2001) Three centuries of whaling and walrus hunting in Svalbard and its impact on the Arctic ecosystem. Environ Hist 7(2): 169-185. https://doi.org/10.3197/096734001129342441

Haggan NB, Neis B, Baird IG (2007) Fishers' knowledge in fisheries science and management. UNESCO Publishing, Paris

Haidt A, Kamiński T, Borowik T, Kowalczyk R (2018) Human and the beast - flight and aggressive responses of European bison to human disturbance. PLoS One 13(8):e0200635. https://doi.org/10.1371/ journal.pone.0200635

Hedemann O (1931) Sprawa o zachowaniu dzikich zwierząt, żubrami nazywanych [Case of conservation of wild animals called European bison]. Echa Leśne 7:9-10 (in Polish)

Hedemann O (1939) L'histoire de la forêt de Białowieża (jusqu'a 1798). Instytut Badawczy Lasów Państwowych, Rozprawy i Sprawozdania Seria A, Nr 1, Warsaw (in Polish with French Summary)

Hofman-Kamińska E, Bocherens H, Drucker DG, Fyfe RM, Gumiński W, Makowiecki D, Pacher M, Piličiauskienė G, Samojlik T, Woodbridge J, Kowalczyk R (2019) Adapt or die - response of large herbivores to environmental changes in Europe 1 during the Holocene

Hofman-Kamińska E, Bocherens H, Borowik T, Drucker DG, Kowalczyk R (2018) Stable isotope signatures of large herbivore foraging habitats across Europe. PLoS One 13:e0190723Link. https://doi.org/10.1371/journal.pone.0190723

Hofman-Kamińska E, Kowalczyk R (2012) Farm crops depredation by European bison (Bison bonasus) in the vicinity of forest habitats in northeastern Poland. Environ Manag 50:530-541

IUCN/SSC (2008) Strategic planning for species conservation: a handbook. Version 1.0. Gland, Switzerland: IUCN Species Survival Commission, $\mathrm{p} 104$

IUCN/SSC (2013) Guidelines for reintroductions and other conservation. Translocations. Version 1.0. Gland, Switzerland: IUCN Species Survival Commission, $\mathrm{p} 72$

Jamrichová E, Hédl R, Koláŕ J, Tóth P, Bobek P, Hajnalová M, Procházka J, Kadlec J, Szabó P (2017) Human impact on open temperate woodlands during the middle Holocene in Central Europe. Rev Palaeobot Palynol 245:55-68

Jarocki FP (1830) O Pusczy Białowiezkiey i o celniejszych w niey zwierzętach [On Białowieża Forest and most prominent animals]. 
In: Jarocki FP (ed) Pisma rozmaite wierszem i proza, 2nd edn. Drukarnia Józefa Węckiego, Warsaw, pp 231-281 (in Polish)

Jędrzejewska B, Jędrzejewski W, Bunevich AN, Miłkowski L, Krasiński ZA (1997) Factors shaping population densities and increase rates of ungulates in Białowieża Primeval Forest (Poland and Belarus) in the 19th and 20th centuries. Acta Theriol 42(4):399-451

Jędrzejewska B, Jędrzejewski W (1998) Predation in vertebrate communities. The Białowieża Forest as a case study, vol 450. SpringerVerlag, Berlin

Karcov G (1903) Belovezhskaya Pushcha. Ee istoricheskii ocherk, sovremennoe okhotniche khozaistvo i vysochaishe okhoty $\mathrm{v}$ Pushche [Białowieża Forest. Its historical description, contemporary game management and monarchical hunts in the forest]. A. Marks, St. Petersburg, 414 (in Russian)

Kerley GIH, Kowalczyk R, Cromsigt JPGM (2012) Conservation implications of the refugee species concept and the European bison: king of the forest or refugee in a marginal habitat? Ecography 35(6):519 529

Kołodziej-Sobocińska M, Pyziel AM, Demiaszkiewicz AW, Borowik T, Kowalczyk R (2016) Pattern of parasite egg shedding by European bison (Bison bonasus) in the Białowieża Primeval Forest, Poland. Mammal Research 61(3):179-186

Kowalczyk R, Krasińska M, Kamiński T, Górny M, Struś P, HofmanKamińska E, Krasiński ZA (2013) Movements of European bison (Bison bonasus) beyond the Białowieża Forest (NE Poland): range expansion or partial migrations? Acta Theriol 58(4):391-401

Kowalczyk R, Taberlet P, Coissac E, Valentini A, Miquel C, Kamiński T, Wójcik JM (2011) Influence of management practices on large herbivore diet - case of European bison in Białowieża Primeval Forest (Poland). For Ecol Manag 261:821-828

Krasińska M, Krasiński ZA (2013) European bison. The nature monograph, vol 398. Springer-Verlag, Berlin-Heidelberg

Lajus DL, Dmitrieva ZV, Kraikovski AV, Lajus JA, Alexandrov DA (2007) Atlantic salmon fisheries in the White and Barents Sea basins: dynamic of catches in the 17-18th century and comparison with 19-20th century data. Fish Res 87(2-3):240-254. https://doi. org/10.1016/j.fishres.2007.07.001

Lajus J, Kraikovski A, Lajus D (2013) Coastal fisheries in the eastern Baltic Sea (Gulf of Finland) and its basin from the 15 to the early 20th centuries. PLoS One 8(10):e77059. https://doi.org/10.1371/ journal.pone.0077059

Latałowa M, Zimny M, Jędrzejewska B, Samojlik T (2015) Białowieża Primeval Forest: A 2000-year interplay of environmental and cultural forces in Europe's best preserved temperate woodland. In: Kirby KJ, Watkins C (eds) Europe's changing woods and forests: from wildwood to cultural landscapes. Oxfordshire: CABI, pp 243 264

Latałowa M, Zimny M, Pędziszewska A, Kupryjanowicz M (2016) Postglacial histor of Białowieża Forest - vegetation, climate and human activity. Parki Narodowe i Rezerwaty Przyrody 35(1):3-49 (in Polish with English summary)

Lotze HK, Worm B (2009) Historical baselines for large marine animals. Trends Ecol Evol 24(5):254-262. https://doi.org/10.1016/j.tree. 2008.12.004

Matosiuk M, Borkowska A, Świsłocka M, Mirski P, Borowski Z, Krysiuk K, Danilkin AA, Zvychaynaya EY, Saveljev AP, Ratkiewicz M (2014) Unexpected population genetic structure of European roe deer in Poland: an invasion of the mtDNA genome from Siberian roe deer. Mol Ecol 23:2559-2572. https://doi.org/10.1111/mec. 12745

McClenachan L, Ferretti F, Baum JK (2012) From archives to conservation: why historical data are needed to set baselines for marine animals and ecosystems. Conserv Lett 5:349-359

McClenachan L, Cooper AB, Hardt M, McKenzie M, Drew JA (2016) Conservation implications of omitting historical data sources: response to Baisre. Conserv Biol 30(1):226-227
Mendoza M, Palmqvist P (2008) Hypsodonty in ungulates: an adaptation for grass consumption or for foraging in open habitat? J Zool 274(2): $134-142$

Mikusińska A, Zawadzka B, Samojlik T, Jędrzejewska B, Mikusiński G (2013) Quantifying landscape change during the last two centuries in Białowieża Primeval Forest. Appl Veg Sci 16:217-226

Monsarrat S, Kerley GIH (2018) Charismatic species of the past: biases in reporting of large mammals in historical written sources. Biol Conserv 223:68-75

Muths E, Scherer RD, Amburgery SM, Matthews T, Spencer AW, Corn PS (2016) First estimates of the probability of survival in a smallbodied, high-elevation frog (boreal chorus frog, Pseudacris maculata), or how historical data can be useful. Can J Zool 94: 599-606

Mysterud A, Bartoń K, Jędrzejewska B, Krasiński ZA, Niedziałkowska M, Kamler JF, Yoccoz NG, Stenseth NC (2007) Population ecology and conservation of endangered megafauna: the case of European bison (Bison bonasus) in Białowieża Primeval Forest, Poland. Anim Conserv 10:77-87

Olech W, IUCN SSC Bison Specialist Group (2008) Bison bonasus. The IUCN Red List of Threatened Species 2008: e.T2814A9484719. https://doi.org/10.2305/IUCN.UK.2008.RLTS.T2814A9484719. en. Accessed on 30 April 2018

Onar V, Soubrier J, Toker NY, van Loenen A, Llamas B, Siddiq AB, Pasicka E, Tokarska M (2017) Did the historical range of the European bison (Bison bonasus L.) extend further south? - a new finding from the Yenikapı Metro and Marmaray excavation, Turkey. Mammal Research 62:103-109

Papworth SK, Rist J, Coad L, Milner-Gulland EJ (2009) Evidence for shifting baseline syndrome in conservation. Conserv Lett 2:93-100

Pucek Z (ed) (2004) European bison. Status survey and conservation action plan. Pucek Z, Pucek Z, Belousova IP, Krasińska M, Krasiński ZA, Olech W. IUCN/SSC Bison Specialist Group, IUCN. Gland, Switzerland and Cambridge, p 54

Pyziel AM, Kowalczyk R, Demiaszkiewicz AW (2011) The annual cycle of shedding Eimeria oocysts by European bison (Bison bonasus) in the Białowieża Primeval Forest, Poland. J Parasitol 97:737-739

Raczyński J (ed) (2018) European Bison Pedigree Book 2017. Białowieża National Park, Białowieża

Radwan J, Demiaszkiewicz AW, Kowalczyk R, Lachowicz J, Kawałko A, Wójcik JM, Pyziel A, Babik W (2010) An evaluation of two potential risk factors, MHC diversity and host density, for infection by an invasive nematode Ashworthius sidemi in endangered European bison (Bison bonasus). Biol Conserv 143:2049-2053

Ruzkii M (1898) Zubr kak vymiraiushchyi predstavitel nashei fauny. Uchenyie zapiski Kazanskoho veterinarnoho instituta Bison as a doomed member of our fauna. Scientific notes of Kazan Veterinary Institute 15(1): 3-13, (2): 97-106, (5-6): 325-352 (in Russian)

Samojlik T (ed) (2005) Conservation and hunting. Białowieża Forest in the time of kings. Mammal Research Institute PAS, Białowieża, pp $1-90$

Samojlik T, Jędrzejewska B (2010) Historia ochrony żubra w Puszczy Białowieskiej do końca XVIII wieku [The history of the protection of European bison in Białowieża Primeval Forest until the end of the 18th century]. In: Kowalczyk R, Ławreszuk D, Wójcik JM (eds) European bison conservation in the Białowieża Forest. Threats and prospects of the population development. Mammal Research Institute, Polish Academy of Sciences, Białowieża, pp 23-32 (in Polish with English summary)

Samojlik T, Daszkiewicz P, Fedotova A (2017) Żubrze eksponaty z lat 1811-1914 w europejskich kolekcjach naukowych - mało znany aspekt XIX-wiecznej gospodarki łowieckiej w Puszczy Białowieskiej [European bison specimens from 1811-1914 in European science collections - little known aspect of the 19th- 
century game management in Białowieża Primeval Forest]. Sylwan 161(4):341-352 (in Polish with English summary)

Samojlik T, Fedotova A, Kuijper DPJ (2016) Transition from traditional to modern forest management shaped the spatial extent of cattle pasturing in Białowieża Primeval Forest in the nineteenth and twentieth centuries. Ambio 45(8):904-918

Samojlik T, Rotherham I, Jędrzejewska B (2013) Quantifying historic human impacts on forest environments: a case study in Białowieża Forest, Poland. Environ Hist 18(3):576-602

Samojlik T, Selva N, Daszkiewicz P, Fedotova A, Wajrak A, Kuijper DPJ (2018) Lessons from Białowieża Forest on the history of protection and the world's first reintroduction of a large carnivore. Conserv Biol 32:808-816. https://doi.org/10.1111/cobi.13088

Selva N, Teitelbaum CS, Sergiel A, Zwijacz-Kozica T, Zięba F, Bojarska K, Mueller T (2017) Supplementary ungulate feeding affects movement behavior of brown bears. Basic Appl Ecol 24:68-76

Szabó P, Hédl R (2011) Advancing the integration of history and ecology for conservation. Conserv Biol 25:680-687

Szabó P (2015) Historical ecology: past, present and future. Biol Rev 90(4):997-1014

Turvey ST, Crees JJ, Di Fonzo MMI (2015) Historical data as a baseline for conservation: reconstructing long-term faunal extinction dynamics in Late Imperial-modern China. Proc R Soc B 282(1813):20151299

Wanner H, Beer J, Bütikofer J, Crowley TJ, Cubasch U, Flückiger J, Goosse H, Grosjean M, Joos F, Kaplan JO, Küttel M, Müller SA, Prentice IC, Solomina O, Stocker TF, Tarasov P, Wagner M, Widmann M (2008) Mid- to Late Holocene climate change: an overview. Quat Sci Rev 27(19-20):1791-1828

Whittlesey LH, Schullery PD, Bone S, Klein A, White PJ, Rodman AW, Hallac DE (2018) Using historical accounts (1796-1881) to inform contemporary wildlife management in the yellowstone area. Nat Areas J 38(1):99-106

Więcko E (1984) Puszcza Białowieska. Państwowe Wydawnictwo Naukowe, Warszawa, pp 1-309 (in Polish)

Wróblewski K (1927) Żubr Puszczy Białowieskiej. Ogród Zoologiczny w Poznaniu, Poznań in Polish

Publisher's note Springer Nature remains neutral with regard to jurisdictional claims in published maps and institutional affiliations. 